\title{
The Effect of Parental Guidance and Emotional Intelligence on Learning Achievement in Social Science
}

\author{
Ahmad Susanto ${ }^{1 *}$ \\ ${ }^{1}$ Faculty of Education Science, Universitas Muhammadiyah Jakarta \\ *) Corresponding author: ahm_susanto@umj.ac.id
}

\begin{abstract}
The purpose of this study was to determine the effect of parental guidance and emotional intelligence on student learning achievement in social science. The research method was a descriptive survey method. Data collection was done by questionnaires. Data analysis involved descriptive statistical method to find partial and multiple correlation coefficient with $t_{\text {test. }}$ The result showed: 1) there was a significant effect of parental guidance and emotional intelligence together on student learning achievement in social science. Parental guidance and emotional intelligence contributed $64.2 \%$ to the student learning achievement in social science; 2) there was a significant effect of parental guidance on student learning achievement in social sciences. This is evidenced by the acquisition of $\operatorname{sig}=0.037<0.05$ and $t_{\text {count }}=2.114 ; 3$ ) There is a significant effect of emotional intelligence on learning achievement in social sciences. This is evidenced by the $p<0.05$ and $t_{\text {count }}$ of 6.336 .
\end{abstract}

Keywords: emotional intelligence, learning achievement, parental guidance, social sciences

\section{Introduction}

Education is not only done in the school environment which is also a formal educational institution, but education can also be done in the family and community environment. Family education is the first and foremost basis for education. A harmonious and happy family will give birth to children or future generations who are good and responsible.

Learning achievement is the result of the measurement of students after following the learning process in a certain period that can be measured using relevant instruments. The results of preliminary observations show that the learning achievements of students of the first Listening School in the City of South Tangerang in 2017 indicate that student achievement is still largely below the Minimum Mastery Criteria (KKM), so it can be called that student achievement is still low. KKM is determined by each school so that it has different standards.

Many factors affect learning achievement, some from within (internal) and some from outside (external). According to Semiawan (1998: 200), the role of the family is more 
to provide support both in terms of providing facilities and creating a conducive learning atmosphere. The role of parents should be the first person in laying the foundations of education on their children. Then proceed to formal education institutions if they are unable to educate and teach themselves at home. Even though it has been assisted by formal education institutions, educating, teaching, guiding, paying attention and so on to their children, it is still the main obligation and responsibility of parents.

The role of parents in educating children to be more accomplished, both in the school environment, family and society are needed, because the success of students in learning is influenced by several factors, including psychological factors, namely intelligence, interests, talents, motives, and emotions and attention and parental guidance.

To realize ideal educational goals, shared responsibility is needed between the government, the community, and the family or parents. Family as an informal institution in educating children have full responsibility for the success of their children's education. The main tasks of parents include caring for, guiding, nurturing and educating children to be smart and have good moral. Also, as parents, they must be able to provide facilities and fulfill needs for children in learning.

Education in the family environment plays an important role in carrying out informal education because family is the first environment where a child receives an education. In the family, children are instilled moral values and ethics that refer to the development of children. In the family environment too, both direct and indirect education will be easily absorbed by children. This will be created through parental examples in the form of behavior, speech, and actions of parents. The role of parents is also very needed to support the success of children's learning achievements. Parents should always pay attention to their children's achievements at school. Parents are expected to ask about how the child is doing at school, how about the lessons at school, and whether they encounter difficulties or not.

It cannot be denied that there are many facts which state that the success of learning and the achievements of a child are greatly influenced by the guidance and direction of the parents. When parents always control the process of learning their children, it will rise a positive motivation in the child that can encourage them to study hard. Besides, children will not feel alone in bearing the burden of learning and school work because there are always parents who accompany them.

As for emotional intelligence, this also greatly influences the success of children's learning. Emotional intelligence is also believed to be one of the internal factors that affect the success of students in learning in addition to intellectual intelligence. Children who have good emotional intelligence can solve learning problems, especially those concerning problems in self-control, enthusiasm, perseverance and the ability to motivate one self.

\section{Literature Review}

\section{Parental Guidance}

Parental guidance is carried out by parents to their children in conducting home learning activities directed at discipline in learning. This situation can be created if there is an emotional bond between parents and their children. A safe home atmosphere helps 
children to develop themselves towards a good future. Mothers and fathers play an important role, especially in terms of education so that the good and bad performance of children is determined by parental guidance.

Family as the first place of growth and development is very decisive. According to Kartono (1991: 63), parents are the first and foremost capable people who have the right to help their offspring and educate their children. Parents' role in the family can create an emotional bond with their children, create a safe atmosphere at home so that parents or home is a place for children to return, be an example or model for their children, provide discipline and improve children's behavior, and create a network of communication among family members. Supervision and guidance of parents at home is necessary because the guidance of parents can monitor and know all the shortcomings and difficulties of children in learning. Gunarsa (2004: 64) stated that parents play a major role in teaching, educating, providing guidance and learning facilities, and setting an example for children under the applicable norms and moral values.

Guidance from parents can also act as a way to increase discipline, especially in learning. Ahmadi (2005: 82) stated that children learn to need guidance from parents so that adult attitudes and learning responsibilities grow on the child. Learning guidance conducted by parents includes supervising the use of learning time at home, recognizing children's difficulties in learning, helping to overcome the difficulties of children in learning (Chaplin: 2006: 92). The research of Lestari (2012) on families in Suarakarta showed the role of parents, namely to help children reach adulthood, provide feedback and consideration for choices made by the child, help and direct children to success, and raise the child to lead a more productive life. Furthermore, Lestari (2012) argued that parental role is not sufficient to only meet basic needs of children and to train them in basic life skills, but also provide the best for children's material needs, meet children's emotional and psychological needs, and provide the best education opportunities. Child development requires the guidance of parents such as setting a good example, telling good stories, telling good things, building creativity in children, control, guide, and supervise children's behavior (Salahudin, 2011: 83-86).

Thus, parental guidance is an aid given by the father or mother to the child so that the child can solve the problems faced according to the abilities and personality of his children. What things make her child embarrassed and what things make her child afraid. The role of parents in education is to build the foundation of aqidah and morality in children so that children have a strong foundation in following the learning process at school and in their wider environment.

\section{Emotional Intelligence}

Emotional intelligence is a human psychological factor that is much discussed at this time. Emotional intelligence is believed to contribute to individual success in carrying out an activity, in addition to intelligence and spiritual intelligence. Emotional intelligence is one of the factors that encourage the birth of feelings in terms of self-management (Suyudi, 2009: 3). Emotional intelligence as a group of mental abilities helps an individual to recognize and understand his feelings and feelings of others, which leads to the ability to regulate his feelings (Meyer in Alder, 2001: 33). 
According to Goleman (1995: 214), emotional intelligence is the ability of a person to regulate his emotional life with intelligence, maintain emotional harmony and express it through self-awareness skills, self-motivation, empathy, and social skills. If individuals have high emotional intelligence, it will give birth to high social sensitivity, and have the ability to adapt themselves in all forms of conditions. Emotional intelligence indicates the ability to monitor feelings and emotions of yourself and others, sorting out the emotion that arises and using this information to guide one's thoughts and actions (Salovey \& Meyer in Wagner, 1993: 259).

Emotional intelligence holds a very important role because human beings are emotional beings (Mubayidh, 2006: 32). Many times a person makes a daily decision not based on logic but on the basis of their own feelings or emotions. People with low emotional intelligence tend to be overwhelmed by feelings of insecurity, making it difficult to make quick decisions.

So, emotional intelligence is a person's ability to master situations that are full of challenges, control reactions or behavior. Emotional intelligence is the intelligence of feelings in response to reactions to stimuli from inside and outside the individual. Emotional intelligence is a building that is composed of five dimensions, namely knowledge, relationship management, self-motivation, empathy and control of feelings or emotions. Emotional intelligence is important for dealing with emotionally charged situations, a condition that often occurs, a difficult part of developing one's intelligence.

\section{Learning Achievement in Social Science}

Learning achievement according to the Kamus Besar Bahasa Indonesia (2005: 895) means a) mastery of knowledge or skills developed by the subject, usually indicated by test scores or grades given by the teacher, b) abilities that really exist or can be observed (actual ability) and which can be measured directly with certain tests.

According to Djamarah (1994: 24), achievement can also be defined as follows: "value is the final formulation that can be given by the teacher regarding the progress/achievement of student learning during a certain period". So, the achievement is the result of students' efforts during a certain period of doing activities.

Shah (1995: 141), said that learning achievement is defined as the level of success of students achieving the goals set in a teaching program. Indicators of learning achievement are the disclosure of learning outcomes that cover all psychological domains that change as a result of students' learning experiences and processes. The intended domains include the domains of creativity, taste, and intention.

So, learning achievement in social science is the result of the measurement of students which includes cognitive, affective, and psychomotor factors after participating in the learning of social science of process as measured using relevant tests or instruments. 


\section{Methods}

\section{Participants}

Participants consisted of 105 students from 327 students at the Public Middle School in South Tangerang City who were randomly selected. Data were collected by distributing questionnaires.

\section{Analysis}

This study used a survey method and employed multiple regression analysis to analyze the effect of independent variables (parental guidance and emotional intelligence) on the dependent variable (learning achievement in social science). The illustration of the association between the three variables is as follows:

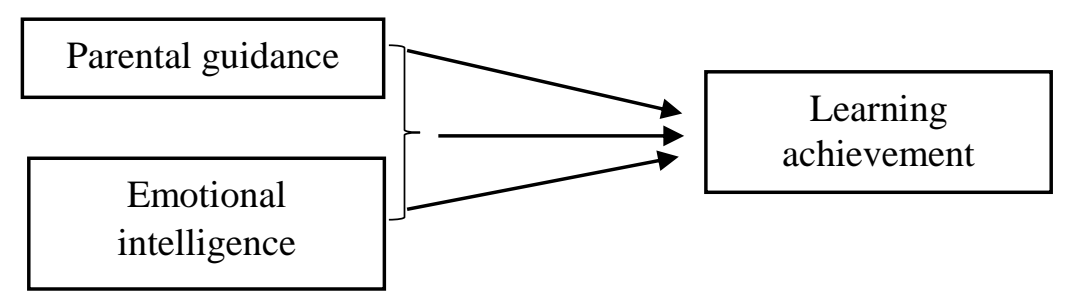

Figure 1. Research model

The regression model equation is as follow:

$$
Y=\alpha+\beta_{1} X_{1}+\beta_{2} X_{2}+\varepsilon
$$

where:

$\mathrm{Y}=$ learning achievement in social science

$\alpha=$ constant

$\beta_{1}=$ regression coefficient of variable $X_{1}$

$\mathrm{X}_{1}=$ parental guidance

$\beta_{2}=$ regression coefficient of variable $X_{2}$

$\mathrm{X}_{2}=$ emotional intelligence

$\varepsilon=$ error

\section{Results and Discussion}

\section{Descriptive Analysis of Research Variables}

Data on parental guidance obtained from questionnaires were answered by 105 students. The score obtained is the lowest score of 50 , the highest score of 125 , the average score is 103.30, the median value is 108.00, the mode value is 121 and the standard deviation is 18.605 (Table 1). 
Table 1. Data description of parental guidance

\begin{tabular}{lr}
\hline Valid & \\
Missing & 105 \\
\hline Mean & 0 \\
Median & 103.30 \\
Mode & 108.00 \\
Standard Deviation & 121 \\
Minimum & 18.605 \\
Maximum & 50 \\
\hline
\end{tabular}

Emotional intelligence data obtained from questionnaires produced the lowest score data of 40 , the highest score of 145 , the average score of 106.84 , the median value of 110.00, and a standard deviation of 24. 591 (Table 2). The results indicate that students' emotional intelligence was relatively good. This is indicated by the acquisition of an average score of 106.84 decoding the median value.

Table 2. Data description of emotional intelligence

\begin{tabular}{lr}
\hline Nalid & 105 \\
Missing & 0 \\
\hline Mean & 106.84 \\
Median & 110.00 \\
Mode & 112 \\
Standard Deviation & 24.591 \\
Minimum & 40 \\
Maximum & 145 \\
\hline
\end{tabular}

Data of student learning achievement were obtained from questionnaires answered by students that produce the lowest score of 5 , highest score of 20 , an average score of 13.67, the median value of 14 , mode value of 12 , and standard deviation of 3.850 (Table 3). From the results, it can be said that the learning achievements of social sciences fell into a fairly good category. This is indicated by the acquisition of an average score of 13.67 near the median value.

Table 3. Data description of learning achievement in social science

\begin{tabular}{lr}
\hline Valid & 105 \\
Missing & 0 \\
\hline Mean & 13.67 \\
Median & 14.00 \\
Mode & 12 \\
Standard Deviation & 3.850 \\
Minimum & 5 \\
Maximum & 20 \\
\hline
\end{tabular}

The result of the regression analysis is presented in Table 4. The multiple linear regression equation was obtained as follows: 


$$
\mathrm{y}=6.336+0.037 \mathrm{X}_{1}+0.295 \mathrm{X}_{2}
$$

From the analysis, it was found that the model was statistically significant $(p<0.05)$. This indicates that parental guidance and emotional intelligence together significantly predicted student learning achievement in social science. The adjusted R-square of 0.642 indicates that as much as $64.2 \%$ of the variance in the measure of student learning achievement in social science could be predicted by the measures of parental guidance and emotional intelligence whereas the rest $35.8 \%$ was predicted by other factors that were not analyzed in this research.

Independently, parental guidance positively affected student learning achievement in social science $(\mathrm{B}=0.37 ; p<0.05)$. The better parental guidance, the better student learning achievement in social science. Statistically speaking, every increase in one point of parental guidance will increase learning achievement in social science by 0.37 point. Also, emotional intelligence showed positive influence on student learning achievement in social science $(\mathrm{B}=0.295, p<0.05)$. Thus, the better student emotional intelligence, the better student learning achievement in social science. It indicates that every increase in one point of parental guidance will increase learning achievement in social science by 0.295 .

Table 4. Result of regression analysis of parental guidance, emotional intelligence, and learning achievement in social science

\begin{tabular}{|c|c|c|c|c|c|}
\hline \multirow{2}{*}{ Variable } & \multicolumn{2}{|c|}{ Unstandardized Coefficients } & \multirow{2}{*}{$\frac{\text { Standardized Coefficients }}{\text { Beta }}$} & \multirow[b]{2}{*}{$\mathrm{t}$} & \multirow{2}{*}{$p$-value } \\
\hline & $\mathrm{B}$ & Std. Error & & & \\
\hline Constant & 6.336 & 12.799 & & .651 & $.037 *$ \\
\hline Parental guidance & .037 & .127 & .380 & 2.114 & $.005 *$ \\
\hline Emotional intelligence & .295 & .128 & .300 & 1.98 & $.025 *$ \\
\hline $\begin{array}{l}\mathrm{F} \\
\text { Adjusted R square } \\
p \text {-value }\end{array}$ & & & $\begin{array}{c}-1.236 \\
0.642 \\
\mathbf{0 . 0 4 3} *\end{array}$ & & \\
\hline
\end{tabular}

Note. $\left.{ }^{*}\right)$ significant at $p<0.05,(* *)$ significant at $p<0.001$

\section{Discussion}

This research was conducted on 327 middle-school students in South Tangerang City to examine the effects of parental guidance and student emotional intelligence on student learning achievement in social science. According to the synthesis of existing theories, parental guidance is a process of providing continuous and systematic assistance from parents to children to achieve independence in self-understanding of self-realization, in achieving optimal levels of development and adaptation to their environment. Emotional intelligence is a person's ability to master challenging situations that can usually cause tension and anxiety. If someone has intelligence on the dimension of emotional life, then he can successfully control his reaction or behavior in such a way that is not affected by the failure. Meanwhile, learning achievement in social science is an attempt to increase or maintain the highest possible skills possessed to achieve learning goals and work to achieve certain standards of excellence, which are expressed verbally. In other words, this construct 
refers to the level of attainment of students' knowledge on social science as well as the attainment of skills and attitudes associated with insights about social science.

The regression analysis found that parental guidance positively affected student learning achievement in social science. Students whose parents spend much time on guiding and assisting their learning process in social science are more likely to have better leaning achievement in social science. The parental guidance in this regard is not limited to parents' help in doing schoolwork, but more than that is parents' role in setting good example as how to behave and communicate with other people in a social setting. This finding is in line with the hypothesis and other prior research on this topic. Uminingsih (2016) found similar finding on student learning achievement in natural science. Schools play a role in educating and forging students with an emphasis on formal lessons whereas families, especially parents, play a role in guiding students with an emphasis on forming the personality of students as a basis for readiness to accept formal learning by the school (Uminingsih, 2016).

As an important aspect of parental guidance, communication between parents and children also plays a role in realizing good parental guidance. Another study found that parent-child communication predicted academic achievement in social science among 8thgrade students (Rahman \& Rochayati, 2015). The more frequent parents communicate with their child, the better child's academic achievement in social science subject (Rahman \& Rochayati, 2015). Rahman and Rochayari (2015) argued that harmonious communication between parents and child is an understanding and compassionate communication, accompanied by guidance and if necessary penalties for the success of children's own learning.

This research also found that emotional intelligence positively affected student learning achievement. Thus, students with higher levels of emotional intelligence are more likely to show better learning achievement in social science. The result of this research is in accordance with the study of Hadwijaya and Hutasoit (2017) which found that emotional intelligence which consists of self-awareness, self-management, motivation, social awareness, and relationship management partially and simultaneously showed positive influences on learning achievement among middle school students. Purnama (2016) argued that emotionally intelligent students have the ability to motivate themselves well and to control their emotions so that they are able to focus their attention on the lesson.

Emotional intelligence allows an individual to recognize and respond to their own feelings well. Purwati and Nurhasanah (2016) in their research found that students with good emotional intelligence showed better academic achievement. They suggested that students who have good emotional skills, characterized by good self-regulation and social skills, are more likely to succeed in life and have the motivation to excel, which result in an increase in their school marks. On the contrary, students who cannot control his emotions will experience inner battles that harm his ability to focus on school, which result in a decreased school marks.

Simultaneously, this research found that the better parental guidance and the higher emotional intelligence that the students have, the higher their learning achievement in social science. It indicates that continuous parental guidance balanced with emotional intelligence in controlling their emotion and persistence in studying will move and direct 
their pedagogical abilities especially in achieving knowledge, skills, and attitudes in social science subjects, towards better learning achievements.

\section{Conclusion and Recommendation}

Based on the data description and data analysis, it can be concluded that parental guidance and emotional intelligence positively influence student learning achievement in social science. Students whose receive better parental guidance and have better emotional intelligence are more likely to perform better in social science subjects at school. The finding of this study proves prior research on the same topic. Based on the conclusion, it can be recommended as follows: First, parental guidance is proven to predict students' success in learning social science subjects. Therefore, parents are expected to put more attention and efforts in their child's learning activities and get more involved in guiding and assisting child's learning activities. In this regard, schools should engage parents in students' learning process, one of which, by providing counseling about the importance of parental guidance to support students' learning and improve their learning achievement at school. Second, emotional intelligence is also found to be influential on student learning achievement in social science. As the closest environment, students' family especially parents should help them to improve their emotional intelligence, such as by conversing more about children's feelings and emotion, acknowledging and empathizing to children's feelings, and helping children to express their emotions in a good way. Schools should also consider the uniqueness of personality of every student, thus teacher are expected to not only teach lessons but also to assist the students to develop their emotional intelligence. These ways are expected to help the students performing better at school.

\section{References}

Ahmadi, A. (2005). Psikologi Perkembangan, Jakarta: Rineka Cipta

Alder, H. (2001). Boost Your Intelligence: Pacu EQ dan IQ Anda. (C. Prianingsih, Trans.). Surabaya: Usaha Nasional

Badudu, J. S. (2005). Kamus Besar Bahasa Indonesia. Jakarta: Sinar Harapan

Chaplin, J. P. (2006). Kamus Lengkap Psikologi. Jakarta: Grasindo

Djamarah, S. B. (1994). Prestasi Belajar dan Kompetensi Guru. Surabaya: Usaha Nasional

Goleman, D. (1995). Emotional Intelligence. New York: Scientific American

Gunarsa, S. D. (2004). Psikologi Perkembangan Anak dan Remaja. Jakarta: Gunung Mulia

Hadiwijaya, H., \& Hutasoi, G. (2017). Effect of emotional intelligence on student learning achievement. Guidena, 7(1), 29-39. http://dx.doi.org/10.24127/gdn.v7i1.663

Kartono, K. (1991). Psikologi Perkembangan Anak. Bandung: PT. Remaja Rosdakarya

Lestari, S. (2012). Psikologi Keluarga. Jakarta: Kencana

Mubayidh, M. (2006). Guru Sebagai Profesi, Yogyakarta: Hikayat Publishing.

Ngermanto, A. (2001). Quantum Quotien/Kecerdasan Quantum. Bandung: Sinar Baru

Noehi, N. (1996). Psikologi Pendidikan. Jakarta: Depdikbud

Nurkancna, W. (1993). Pemahaman Individu. Surabaya: Usaha Nasional

Purnama, I. M. (2016). Pengaruh kecerdasan emosional dan minat belajar terhadap prestasi belajar Matematika di SMAN Jakarta Selatan. Jurnal Formatif, 6(3), 233-245. 
Purwati, \& Hasanah. (2016). Deskripsi pengaruh kecerdasan emosional terhadap prestasi belajar mahasiswa Pendidikan Matematika UNIPA. Pancaran, 5(4), 169-178.

Rahman, M. Z., \& Rochayati, N. (2015). Pengaruh komunikasi orang tua dan motivasi belajar siswa terhadap prestaso be;ajar IPS (siswa kelas VIII SMP Negeri 2 Sakra Barat Kabupaten Lombok Timur NTB). Paedagoria, 11(1), 61-69.

Surya, M., \& Natawidjaya, R. (1995). Pengantar Bimbingan dan Penyuluhan. Jakarta: Depdikbud

Susanto, A. (2018). Bimbingan dan Konseling di Sekolah. Jakarta: Prenada

Suyudi, M. (2001). Pendidikan dalam Perspektif Al-Quran, Integrasi Epistemologi. Jogjakarta: UIN Sunan Kalijaga

Syah, M. (1995). Psikologi Pendidikan Susatu Pendekatan Baru. Bandung: PT. Remaja Rosda Karya

Uminingsih. (2016). Pengaruh bimbingan orang tua terhadap prestasi belajar IPA siswa kelas VI SDN 004 Bontang. Cendekia, 10(1), 55-66. http://dx.doi.org/10.30957/cendekia.v10i1.82

Wagner, W. W. (1988). Principles of Instructional Design (3rd ed.). New York: HaltRichart and Winston, Inc.

Winkel, W. S. (1996). Psikologi Pengajaran. Jakarta: Grasindo 